\title{
Collagen Type IV Alpha-3-Binding Protein
}

National Cancer Institute

\section{Source}

National Cancer Institute. Collagen Type IV Alpha-3-Binding Protein. NCI Thesaurus. Code $C 91070$.

Collagen type IV alpha-3-binding protein ( $624 \mathrm{aa}, \sim 71 \mathrm{kDa}$ ) is encoded by the human COL4A3BP gene. This protein may play a role in the mediation of ceramide transport. 